\title{
PRUDENTIAL REGULATIONS AND PROFITABILITY: EMPIRICAL EVIDENCE FROM MICROFINANCE BANKS IN KENYA
}

\author{
${ }^{1}$ Malgit Amos Akims PhD, ${ }^{2}$ Joseph Munyao Kiio, ${ }^{3}$ Salome Jemutai Tenai \& ${ }^{4}$ Kanang Amos Akims PhD \\ $\left({ }^{1}\right.$ Department of Public Policy and Administration, \\ School of Humanities and Social Sciences, Kenyatta University, Nairobi Kenya \\ Email: malgitakims@gmail.com, \\ ${ }^{2}$ Accounting and Finance Department, School of Business and Management, Kiriri Women's University of \\ Science and Technology, \\ ${ }^{3}$ Department of Accounting and Finance, School of Business, Kenyatta University, Nairobi Kenya \\ ${ }^{4}$ Department of Economics, Faculty of Social Sciences, University of Jos, Jos Nigeria \\ Email: akimskb@gmail.com)
}

\begin{abstract}
Microfinance banks carry out important roles in the economic growth and development of countries. In order to protect depositors, governments have introduced legislations and regulations to guide the activities of Microfinance banks. Over the years in Kenya, several regulations have been put in place by the Central Bank. However, the underlying argument is whether prudential regulations significantly contribute to the profitability of Microfinance banks in Kenya. In view of this, the study sought to examine the effect of prudential regulations on profitability of Microfinance Banks in Kenya. Agency Theory and Capital Buffer Theory were adopted to support the relationship between prudential regulations and profitability. Descriptive analysis and panel regression analysis were applied in the study. The hypotheses testing were based on the threshold of 0.05 significance level. It was found that capital regulation and liquidity regulation had insignificant effect on profitability of Microfinance Banks in Kenya. The study established that credit regulation had significant effect $(\beta=-5.016$ and $p$-value $=0.038)$ on profitability of Microfinance Banks in Kenya. The study recommends that the managers of Microfinance banks in Kenya should tighten their credit risk management through effective assessment and monitoring. This will in turn reduce the rate of non-performing as well as the bad debts written-off against profits. The study suggests that further research can be done on the effect of capital regulation and liquidity regulation on profitability of Microfinance Banks in Kenya. Through this, the insignificant effect of capital regulation and liquidity regulation on profitability can be probed or further examined which can be based on different methodology such as time period and/or measures of variables.
\end{abstract}

Keywords: Prudential Regulations, Capital Regulation, Liquidity Regulation, Credit Regulation, Profitability and Microfinance Banks

DOI: $10.7176 /$ RJFA/12-24-04

Publication date: December $31^{\text {st }} 2021$

\subsection{Research Methodology}

Explanatory research design was adopted and the study was based on all the thirteen (13) licensed microfinance banks in Kenya, thereby adopting a census approach. As such, secondary data was sourced from the published financial statements of these banks covering the period 2013 to 2019. Panel regression analysis was applied and the regression model took the following form:

$\mathrm{PRO}_{\text {it }}=\beta_{0}+\beta_{1} \mathrm{CAR}_{\mathrm{it}}+\beta_{2} \mathrm{LIR}_{\mathrm{it}}+\beta_{3} \mathrm{CRE}_{\mathrm{it}}+\beta_{3} \mathrm{BAS}_{\mathrm{it}}+\varepsilon$

Where:

PRO = Profitability (Return on Equity: Net income/shareholders' equity)

CAR = Capital Regulation (Core capital/total assets)

LIR = Liquidity Regulation (Liquid assets/total assets)

$\mathrm{CRE}=$ Credit Regulation (Non-performing loans/total loans)

BAS = Bank Size (Log of total assets, control variable)

$\mathrm{i} \quad=$ Bank 
$\mathrm{t}=$ Time period

$\beta=$ Regression Coefficients

$\varepsilon=$ Error term

\subsection{Empirical Analyses and Discussions}

This section documents the descriptive analysis, model specification tests and panel regression analysis.

\subsection{Descriptive Analysis}

This section documents the descriptive analysis of the study. Statistics such as mean, standard deviation, minimum and maximum observations are presented which in turn provided the basic features of the data used in the study. The descriptive statistics are documented in Table 4.1.

Table 4.1: Descriptive Statistics

\begin{tabular}{llcccc}
\hline Variable & Obs & Mean & Std. Dev. & Min & Max \\
\hline Profitability & 72 & -0.44 & 1.85 & -14.88 & -0.52 \\
Capital Regulation & 72 & 0.27 & 0.25 & 0.06 & 0.84 \\
Liquidity Regulation & 72 & 0.22 & 0.13 & 0.00 & 0.70 \\
Credit Regulation & 72 & 0.16 & 0.11 & 1.89 & 0.42 \\
Bank Size & 72 & 3.04 & 0.85 & 4.51 \\
\hline
\end{tabular}

Source: Study Data (2021)

Table 4.1 indicates that profitability of Microfinance banks as measures by return on equity had a mean of -0.44 and corresponding standard deviation of 1.85 . The statistics notably indicate high fluctuations in the profitability of Microfinance banks. Capital regulation had mean and standard deviation of 0.27 and 0.25 respectively. Liquidity regulation had mean of 0.22 and standard deviation of 0.13 . Credit regulation had mean and standard deviation of 0.16 and 0.11 . Capital regulation, liquidity regulation and credit regulation therefore had minimal fluctuations. Bank size which was the control variable had mean of 3.04 and standard deviation of 0.85 .

\subsection{Model Specification Test}

In order to select the best model for estimation, the model specification test was conducted which was based on hausman specific test. The hausman specification test is based on random effect and fixed effect models. The results of the hausman specification test are presented in Table 4.2.

Table 4.2: Hausman Specification Test

\begin{tabular}{|c|c|c|c|c|}
\hline \multicolumn{5}{|l|}{ Profitability } \\
\hline & (b) & (B) & (b-B) & $\operatorname{Sqrt}\left(\operatorname{diag}\left(\mathbf{V} \_b-V \_B\right)\right)$ \\
\hline & Fixed & Random & Difference & S.E. \\
\hline Capital Regulation & 0.7897544 & 1.488986 & -0.6992313 & 0.6796326 \\
\hline Liquidity Regulation & 0.1303314 & -0.8732767 & 1.003608 & 1.042753 \\
\hline Credit Regulation & -7.10115 & -5.016723 & -2.084427 & 1.656259 \\
\hline Bank Size & 1.098491 & 0.6157778 & 0.4827135 & 1.158502 \\
\hline $\operatorname{chi} 2(4) 2.06$ & 0.7249 & & & \\
\hline
\end{tabular}

Source: Study Data (2021)

The hausman specification test was based on the null hypothesis which stated that the random effect model is the preferred model which was informed by a threshold of 0.05 significance level. The outcome of the hausman specification test in Table 4.2 indicates a p-value of 0.7249 which is above the threshold of 0.05 , therefore, the null hypothesis was not rejected. The study used the random effect model for estimation.

\subsection{Panel Regression Analysis}


The panel regression analysis was used in testing the null hypotheses which were formulated in line with the specific objectives of the study. The results of the panel regression analysis are presented in Table 4.3

Table 4.3: Panel Regression Results

\begin{tabular}{|c|c|c|c|c|c|c|}
\hline Profitability & Coef. & Std. Err. & $\mathbf{z}$ & $\mathbf{P}>|\mathbf{z}|$ & [95\% Conf. & Interval] \\
\hline Capital regulation & 1.488986 & 1.115271 & 1.34 & 0.182 & -0.696906 & 3.674877 \\
\hline Liquidity Regulation & -0.8732767 & 1.79836 & -0.49 & 0.627 & -4.397997 & 2.651443 \\
\hline Credit Regulation & -5.016723 & 2.423438 & -2.07 & 0.038 & -9.766574 & -0.2668732 \\
\hline Bank Size & 0.6157778 & 0.4962667 & 1.24 & 0.215 & -0.3568871 & 1.588443 \\
\hline cons & -1.812254 & 1.818671 & -1.00 & 0.319 & -5.376783 & 1.752275 \\
\hline$=0.1393$ & & & & & & \\
\hline \multicolumn{7}{|l|}{ Wald chi2 $(4)=11.33$} \\
\hline Prob $>$ chi $2=0.0231$ & & & & & & \\
\hline
\end{tabular}

Source: Study Data (2021)

\subsection{Hypotheses Testing}

Table 4.3 indicates an R squared of 0.1393 which implies that 13.93 of the predictor variables in the model were explained by the predictor variables. Probability value of 0.0231 indicates significance of the model which is desired in a regression analysis. Bank size was used as the control variable; as such its effect on profitability was controlled. The study sought to examine the effect of prudential regulations on profitability of Microfinance Banks in Kenya. In order to achieve this objective, three specific objectives and three corresponding null hypothesis were formulated. The first specific objective was to determine the effect of capital regulation on financial stability of Microfinance Banks in Kenya. A corresponding null hypothesis which stated that capital regulation has no significant effect on profitability of Microfinance Banks in Kenya was formulated and tested. The panel regression analysis indicates a p-value of 0.182 and a coefficient of 1.489. This implies that capital regulation had no significant effect on profitability of Microfinance Banks in Kenya. As such, the null hypothesis was upheld at 0.05 significance level.

The second specific objective was to examine the effect of liquidity regulation on profitability of Microfinance Banks in Kenya. Consequently, a null hypothesis was formulated and tested which stated that liquidity regulation has no significant effect on profitability of Microfinance Banks in Kenya. A p-value of 0.627 and coefficient of 0.873 were obtained which indicates that liquidity regulation has no significant effect on profitability of Microfinance Banks in Kenya. The third specific objective was to assess the effect of credit regulation on profitability of Microfinance Banks in Kenya. In order to achieve this objective, a null hypothesis was tested which stated that credit regulation has no significant effect on profitability of Microfinance Banks in Kenya. The results from the panel regression analysis indicate a p-value of 0.038 and a coefficient of -5.016 which implies that credit regulation had significant effect on profitability of Microfinance Banks in Kenya. A unit increase in credit regulation as measured by non-performing loans to total loans ratio leads to a corresponding decrease in profitability by 5.016 . The negative effect can be attributed to the notion that increases in non-performing loans leads to increases in bad debts which are subsequently written off against profits.

\subsection{Conclusion and Recommendations}

The study sought to examine the effect of prudential regulations on profitability of Microfinance Banks in Kenya. The study established that credit regulation had significant effect on profitability of Microfinance Banks in Kenya. The study recommends that the managers of Microfinance banks in Kenya should tighten their credit risk management through effective assessment and monitoring. This will in turn reduce the rate of non-performing as well as the bad debts written-off against profits. It was found that capital regulation and liquidity regulation had insignificant effect on profitability of Microfinance Banks in Kenya. The study recommends that the managers should consider other factors alongside prudential regulations in formulating policies governing the running of the Microfinance banks in Kenya.

\subsection{Suggestions for Further Research}


The study suggests that further research can be done on the effect of capital regulation and liquidity regulation on profitability of Microfinance Banks in Kenya. Through this, the insignificant effect of capital regulation and liquidity regulation on profitability can be probed or further examined which can be based on different methodology such as time period and/or measures of variables.

\subsection{Introduction and Background}

Microfinance institutions (MFIs) perform significant roles in the economic development of several developing nations (David \& Muendo, 2018). Despite this lack of sound regulations in the past, these institutions have over the years made rapid growth in several countries which led to the need of having regulations, which are regarded as fundamental for optimum financial performance. In a move to protect depositors, several governments introduced legislations and regulations relating to Microfinance with different countries adopting different models of Microfinance banks (Cull, Demirg-Kunt \& Morduch, 2009). Prudential regulations are regarded as set of commands by a government which subjects the banking sector into certain restrictions, requirements as well as guidelines as stipulated by the apex regulatory body such as Central Bank. These regulations are brought forward for purposes of ensuring market transparency which cuts across the banking industry and individuals or banking institutions and other institutions that they carry out business activities with.

In Kenya, the statutory requirement stipulates that MFBs should have liquidity ratio of $20 \%$ always. On capital threshold, the MFBs ought to adhere to ratios of $10 \%$ and $20 \%$ with respect to maintaining Total Assets to Total Risk Weighted Assets (TRWA) and Core Capital to TRWA respectively. The capital requirement for nationwide Microfinance banks was of Kshs. 60 million and that of community Microfinance banks at Kshs. 20 million. The Microfinance Act, 2006 and the Microfinance (Deposit Taking Institutions) Regulations 2008 provides the legal, supervisory and regulatory frameworks for the microfinance industry in Kenya. David and Muendo (2018) contend that complying with the regulations can be costly to financial institutions thereby affecting financial performance. The regulatory frameworks for microfinance are stringent and as such leading to sub-optimal financial performance (Debapratim, Trilochan \& Biswajit, 2014).

Notably, for justifiable intermediation role, Microfinance banks require to be profitable. Profitability in the banking sector is of key importance because it facilitates the financial intermediation role carried out by banks. At the micro level, profitability is considered a necessity as it ensures the survival of banks while serving as a major source of earnings to shareholders and as well as retained earnings for banks (Akims \& Akims, 2019). Ultimately, at the macro level, bank profitability cushions against adverse shocks and as such bringing about sustainability in the financial system (Akims, 2020). However, Microfinance banks have been faced with issues pertaining profit generation. In the year 2010, one of the two licensed Microfinance banks recorded losses. In the year 2011, losses were similarly recorded by three out of the six licensed Microfinance banks (King'ori, Kioko \& Shikumo, 2017). Also, one out of the six licensed Microfinance banks recorded losses in the following 2012 while in the year 2013, losses were recorded by four out of the nine licensed Microfinance banks. Only two MFBs did not record losses between 2010 and 2016 out of the 13 institutions licensed (Central Bank Kenya, 2016).

The financial sector of Kenya has been hit by the coronavirus pandemic and banks had declining profitability. The profitability of Microfinance banking sector in terms of profit after tax witnessed a decline of 17.2\% (Sh134.1 billion) in June 30, 2020 as a result of increased expenditure of 11.9\% (Sh404.1 billion) in June 2020 which was further driven by increase in bad debt charge of 150.8\% (Central Bank of Kenya, 2020). Microfinance Banks unlike commercial banks have lower capacity of absorbing high losses and/or restructuring loans. Despite the introduction of prudential regulations by the Central Bank, few empirical studies have been done to establish its effect on profitability of Microfinance banks in Kenya. Theoretical linkages have been established in literature between prudential regulations and profitability; however, it remains largely unclear whether these regulations significantly contribute to profitability in the context of Microfinance Banks in Kenya. This therefore forms a basis for this study as it sought to empirically examine the effect of prudential regulations on profitability of Microfinance Banks in Kenya.

\subsection{Objectives of the Study}

\subsubsection{General Objective}

The general objective of the study was to examine the effect of prudential regulations on profitability of Microfinance Banks in Kenya.

\subsubsection{Specific Objectives}

The specific objectives of the study were: 
i. To determine the effect of capital regulation on Profitability of Microfinance Banks in Kenya.

ii. To examine the effect of liquidity regulation on profitability of Microfinance Banks in Kenya

iii. To assess the effect of credit regulation on profitability of Microfinance Banks in Kenya.

\subsection{Research Hypotheses}

In view of the specific objectives, the following null hypotheses were formulated and tested: $\mathrm{H}_{01}$ : Capital regulation has no significant effect on profitability of Microfinance Banks in Kenya $\mathrm{H}_{02}$ : Liquidity regulation has no significant effect on profitability of Microfinance Banks in Kenya. $\mathrm{H}_{03}$ : Credit regulation has no significant effect on profitability of Microfinance Banks in Kenya.

\subsection{Literature Review}

\subsection{Theoretical Review}

Agency Theory was introduced by Jensen and Meckling (1976). Daily, Dalton and Canella (2003) contend that two major factors which make up the theory brought it to prominence. The theory views an entity from the perspective of principal and agent relationships. The shareholders are considered as the principal while the managers agents. The general notion of humans having self-interest also forms leads to agency problems which forms a key part of the theory. In view of agency relationships, the agents (managers) are entrusted by the principal (owners) with the responsibility of managing the affairs of the institution. The profitability of Microfinance banks is therefore dependent of the way managers handle the affairs of the bank. The Capital Buffer Theory was introduced by Calem and Rob (1996). The theory holds the assertion that upon reaching the minimum regulatory (stipulated) capital ratio a bank may strive towards raising additional capital for purposes of minimizing the likelihood of falling below the stipulated capital requirements as this comes with underlying regulatory costs. The Capital Buffer Theory holds that banks with low capital buffers strive to have additional capital buffer. Also, banks with high levels of capital strive to maintain such capital levels as this provides more capacity of cushioning against adverse economic conditions. This reduces the likelihood of collapse or failure of banks. In view of capital buffer of banks serving as a key factor of capital adequacy, the prepositions of capital buffer theory support the relationship between capital regulation and profitability.

\subsection{Empirical Review}

Wanjiru (2016) studied the effect of regulations on financial performance of MFBs in Kenya. The study considered liquidity, capital adequacy and asset quality requirements. Financial performance was assessed using return on equity and return on assets. Asset quality had significant effect on return on equity while capital adequacy and liquidity requirement had insignificant effect on return on equity. Capital adequacy had significant effect on return on assets. However, asset quality and liquidity requirements had insignificant effect on return on assets of Microfinance banks in Kenya. Notably, the study only considered five (5) Microfinance banks whereas this study will be based on a census approach. The previous study focused on the period 2010 to 2014 while the current study covered the period 2013 to 2019.

Ndolo (2017) assessed the effect of CBK regulations on financial performance of commercial banks listed at the Nairobi Securities Exchange, Kenya. Secondary data was used as collected from the eleven (11) listed commercial banks in Kenya from the period 2012 to 2016. Based on the output of the regression analysis, it was established that liquidity management regulation had insignificant positive on financial performance. Credit risk management regulation had insignificant effect on financial performance. It was further established that capital adequacy regulation had significantly negative effect on financial performance listed commercial banks in Kenya. The current study differs as it focused on Microfinance banks in Kenya.

Buluma, Kung'u and Mungai (2017) studied the effect of SASRA regulations on fiscal performance of Deposit Taking Sacco in Nyandarua County, Kenya. Data was collected using questionnaires from five (5) SASRA licensed SACCOs. It was established that SACCOs in Nyandarua County fully adhered to SASRA regulations. It was found that SASRA regulations led to better financial performance (return on assets) of SACCOs. The study notably was based on SACCOs whereas the current study focused on Microfinance banks in Kenya 
David and Muendo, (2018) analyzed the effect of Central Bank of Kenya regulations on the financial performance of Microfinance banks. The study focused on the 13 Microfinance banks licensed by the Central Bank of Kenya as at 31st December 2016 where a census approach was utilized. All the eighty two (82) staff working in the Risk, Compliance and Finance departments across all Microfinance banks in Kenya formed the sample of the study; as such both primary and secondary data were applied. It was found that capital adequacy had strong effect on financial performance of Microfinance banks greatly. The study documented that operational requirements affect the financial performance of Microfinance banks to a high extent. Despite focusing of Microfinance Banks in Kenya, the empirical analysis was largely based on primary data which can be limited by the subjectivity of respondents.

Mwenda (2018) investigated the effect of prudential regulations on financial performance with focus on microfinance banks in Kenya. Descriptive research design was used and the population was made up of thirteen microfinance banks. Secondary data was used based on the period 2013 to 2017. Capital adequacy had significant positive relationship with financial performance. Liquidity had insignificant positive relationship with performance. Loan loss provisions and financial performance had significant negative relationship. Asset quality had insignificant negative relationship with financial performance of microfinance banks in Kenya. Unlike the previous study which covered the time scope of 2013 to 2017 , the current study further extended by a two year period by analyzing data collected for the years 2013 to 2019.

Akims and Akims (2019) examined the effect of prudential regulations on profitability of commercial banks listed at the Nairobi Securities Exchange, Kenya. The study was based on the period 2013-2017 and panel data was used. As such, panel regression analysis was employed and the study found that capital adequacy regulation had significant positive effect on profitability. Liquidity regulation however, had insignificant negative effect of profitability. Additionally, credit risk regulation had significant negative effect on profitability of commercial banks listed at the Nairobi Securities Exchange, Kenya. In order to sustain profitability, the study recommended that the management of banks should put in place effective polices of credit risk management while embarking on efficient risk minimization practices. The study despite contributing to literature on prudential regulations and profitability, the focus was notably commercial banks which operate on a larger scale as compared to Microfinance banks.

Mugo and Mutsweje (2020) analyzed prudential Regulations and financial performance nexus in the context of commercial banks in Kenya. Forty two (42) commercial banks constituted the population of the study where a census approach was adopted. Secondary data was used for the time period 2013 to 2018. Based on panel regression analysis, it was reported that prudential regulations (capital adequacy regulation, liquidity regulation and credit risk regulation) had significant effect on financial performance of the commercial banks in Kenya. It was recommended that the Central Bank of Kenya should tighten regulations on capital adequacy for purposes of creating more balance in the composition of core capital and total assets thereby bridging the underlying gap between high capital (core capital and total assets) level banks and minimum capital level banks. The study contributes to existing empirical literature on prudential regulations and financial performance nexus in Kenya; however, the findings are limited to commercial banks. Notably when compared to Microfinance Banks, commercial banks operate on a larger scale, hence benefiting from higher operational efficiency and economies of scale.

\section{References}

Akims and Akims (2019). Prudential Regulations and Profitability of Commercial Banks Listed At the Nairobi Securities Exchange, Kenya. IOSR Journal of Economics and Finance (IOSR-JEF), 10 (6), 68-74.

Akims, M. A (2020). Fundamental Risk Factors and Profitability of Commercial Banks in Nigeria. PhD Thesis Submitted to Kenyatta University.

Buluma, F. C. O., Kung'u, J., \&Mungai, F. N. (2017). Effect of SASRA regulations on financial performance of Nyandarua County's deposit taking SACCOs in Kenya. International Journal of Economics, Commerce and Management, 5(7), 614-636.

Calem, P.S., and R. Rob (1996): "The Impact of Capital-Based Regulation on Bank Risk - Taking: A Dynamic Model, Board of Governors of the Federal Reserve System," Finance and Economics Discussion Series 96/12 (February), 36. 
Central Bank Kenya (2020). Bank supervision Annual report. [Online] Available: http://www.centralbank.go.ke.

Central Bank of Kenya (2016). Bank Supervision Annual Report 2015. Nairobi: Central Bank of Kenya.

Cull, R., Demirgüç-Kunt, A., \& Morduch, J. (2009). Microfinance meets the market. Journal of Economic Perspectives, 23(1), 167-192.

David, J. K. \& Muendo, D (2018). Effect of Central Bank Of Kenya Regulations On The Financial Performance Of Microfinance Banks. Strategic Journal of Business and Change Management, 5 (1), 584- 623.

Debapratim, P., Trilochan, T., \& Biswajit, D. (2014). The Impact of regulations on Microfinance industry: A Strategic Perspective, IUP Journal of Business Strategy, 11 (3).

Jensen M, C, \& Meckling W, H. (1976). Theory of the firm: Managerial behavior, agency costs and ownership structure. Journal of Financial Economics, 3(4), 305-360.

King'ori, S., Kioko, W., \&Shikumo, H. (2017). Determinants of financial performance of microfinance banks in Kenya. Research Journal of Finance and Accounting,8(16), 1-8

Mugo, H. W \& Mutsweje, S. V (2020). Prudential Regulations and Financial Performance of Commercial Banks in Kenya. IOSR Journal of Economics and Finance, 11 (4), 16-30.

Mwenda, L (2018). Effect of Prudential Regulations on Financial Performance of Microfinance Banks in Kenya. Msc Project University of Nairobi

Ndolo, A. (2017). Effect of Central Bank of Kenya regulations on the financial performance of commercial banks listed at the Nairobi Securities Exchange in Kenya. MBA Project Submitted to KCA University

Wanjiru, C (2016). Effect of Regulation on the Financial Performance of Microfinance Banks In Kenya: A Survey of Microfinance Banks in Nairobi. MBA Project Submitted to KCA University 